\title{
Effect of airbrush type on sprayed platinum and platinum-cobalt catalyst inks: Benchmarking as PEMFC and performance in an electrochemical hydrogen pump
}

\author{
Luis F. Arenas, ${ }^{\mathrm{a}}$ Georgios Hadjigeorgiou, ${ }^{\mathrm{a}}$ Simon Jones, ${ }^{\mathrm{b}}$ Nick Van Dijk, ${ }^{\mathrm{b}}$ David \\ Hodgson, ${ }^{\mathrm{b}}$ Andy Cruden, ${ }^{\mathrm{a}}$ Carlos Ponce de León ${ }^{\mathrm{a}}$ \\ ${ }^{a}$ Electrochemical Engineering Laboratory, Energy Technology Research Group, Faculty of \\ Engineering and Physical Sciences, University of Southampton, Highfield, Southampton, SO17 1BJ, \\ United Kingdom \\ ${ }^{\mathrm{b}}$ PV3 Technologies Ltd. Unit 5 \& 6, Merchants Quay, Pennygillam Industrial Estate, \\ Launceston, PL15 7QA, United Kingdom
}

\begin{abstract}
Proton-exchange membrane fuel cells and electrochemical hydrogen pumps are based on membrane electrode assemblies containing Pt catalysts. During their preparation, a catalyst ink is usually applied to the gas diffusion layer. Among the available methods, ink spray using an airbrush can be advantageous for making small electrodes at universities and companies. This work compares the suitability of gravity-feed and suction-feed airbrushes during the evaluation of in-house developed Pt and Pt-Co catalysts. The surface morphology of the catalyst layers was analysed by SEM and EDS and related to the preparation technique. The catalysts were compared against an off-the-shelf catalyst. The in-house Pt catalyst afforded similar polarization curves as the commercial catalyst whereas the Pt-Co catalyst exhibited a slightly inferior performance. The suction-feed airbrush was deemed preferable because its produced cracked mud-like, homogeneous and smoother catalyst layers in contrast to the gravity-feed method, which resulted in poor-quality deposits with loose particles, lower Pt utilisation and higher resistance.
\end{abstract}

Keywords: electrochemical hydrogen pump, fuel cell, hydrogen purification, hydrogen storage, membrane electrode assembly, proton-exchange membrane 


\section{Research highlights}

- In-house developed Pt and Pt-Co catalysts are tested in reproducible MEAs.

- The effect of gravity- and suction-fed airbrushes on the catalyst layer is studied.

- Catalysts are benchmarked against Hi-Spec 3000 in fuel cell \& $\mathrm{H}_{2}$ pump modes.

- Suction-fed airbrushes are better for providing a 'cracked mudflat' morphology.

- In-house Pt catalyst was alike Hi-Spec but the Pt-Co catalyst underperformed.

\section{Graphical Abstract}
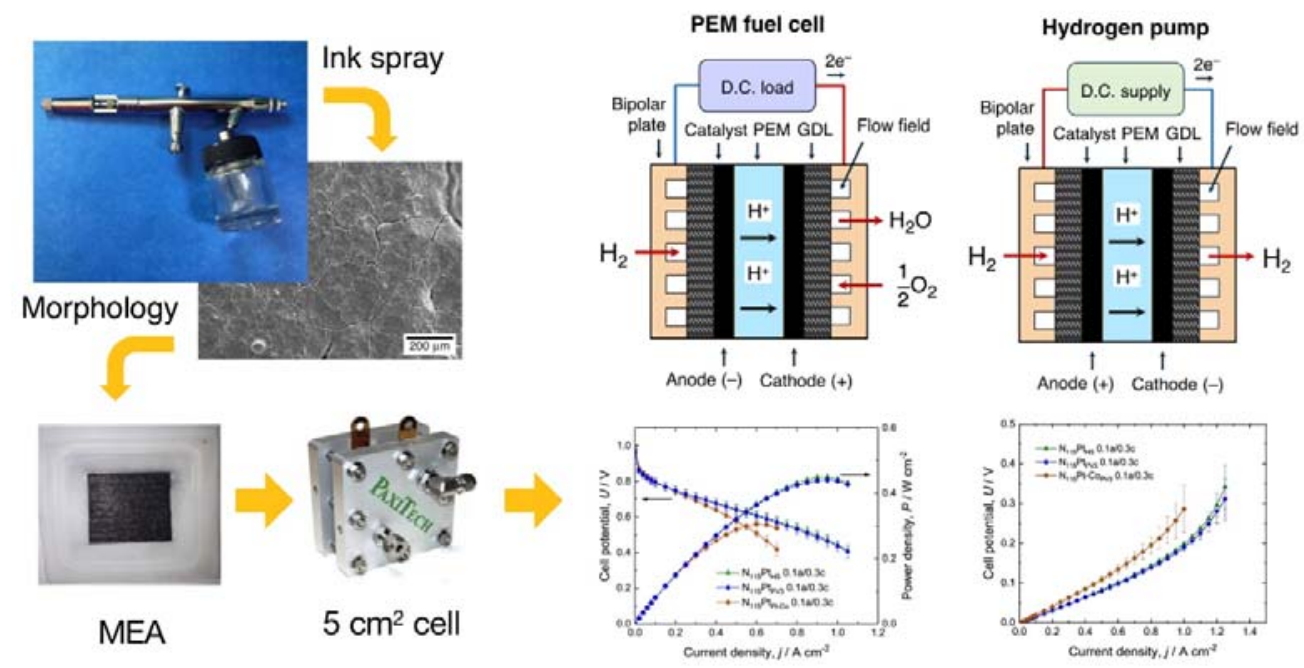


\section{Introduction}

Enduring interest in proton-exchange membrane fuel cells (PEMFCs) is justified on the expected transition from a fossil fuel-based economy into one based on sustainable sources, which might eventually lead to large markets for hydrogen powered technologies [1]. A more immediate driver lies in the prospect of employing PEMFCs in fleets of vehicles in freight and logistics, where they can achieve economic advantages over their battery powered counterparts [2]. Furthermore, as carbon capture technologies advance, it might soon be possible to generate large quantities of 'carbon neutral' hydrogen from natural gas reforming and coal gasification [3], extending the scope of application of hydrogen as an energy vector. As shown in Fig. 1a), the reactions in PEMFCs are the oxidation of hydrogen (HOR) and the reduction of oxygen (ORR) at the anode and cathode, respectively:

$$
\begin{array}{ll}
H_{2(g)} \rightarrow 2 H_{(a q)}^{+}+2 e^{-} & E^{\Theta}=0.0 \mathrm{~V} v s . \text { SHE } \\
\frac{1}{2} O_{2(g)}+2 H_{(a q)}^{+}+2 e^{-} \rightarrow H_{2} O_{(a q)} & E^{\Theta}=1.23 \mathrm{~V} v \text { vs. SHE }
\end{array}
$$

The HOR (1) is much faster than the ORR (2) [4], and therefore the latter is the limiting step in PEMFCs. The overall cell reaction and standard cell potential are:

$$
H_{2(g)}+\frac{1}{2} O_{2(g)} \rightarrow H_{2} O_{(a q)} \quad U^{\Theta}=1.23 \mathrm{~V} v s \text {. SHE }
$$

Platinum supported on carbon continues to be the de facto catalyst for the anode of protonPEMFCs [5,6], while platinum alloys on carbon supports are commonly used to enhance the activity towards the ORR at the cathode and to diminish its susceptibility to poisoning [7]. Cobalt- [8-10] and nickel-platinum [9,11,12] alloys are the most studied. Having a lower content of the precious metal, these alloys can be used as low-cost catalysts in related applications. 
On the other hand, electrochemical hydrogen pumps (EHPs) have received increasing attention due to their promising impact in hydrogen compression and purification [13]. Just like PEMFCs, these devices are based on membrane electrode assemblies (MEAs) containing platinum catalysts. However, EHPs are electrolytic cells involving only hydrogen-related reactions [14], as explained below. Electrochemical compressors are seen as an efficient alternative to mechanical devices in low-power settings $[15,16]$, e.g., in situ hydrogen storage in solar and wind farms. Refuelling stations for hydrogen powered vehicles, requiring standard storage pressures of 350 or 700 bar [17], are obvious applications. EHPs are also being explored in the field of heat pumps [18], while its modality for gas purification is used to produce very pure hydrogen for the manufacture of LEDs and other semiconductors [19]. Another use is the recovery of gases from hydrogen-containing mixtures, e.g., oxygen in space vehicles [20], and valuable helium in rocket engine testing facilities [21]. The separation of hydrogen from methane [22] and ethylene [23] mixtures and from $\mathrm{CO}_{2}$-rich reformate [24,25], has also been considered, despite the challenges set by the poisoning of platinum-based catalysts in these environments.

As shown in Fig. 1b), molecular hydrogen is oxidised (HOR) at the anode of an EHP, producing hydrated protons which are transferred through the proton-exchange membrane (PEM) by migration $[14,26]$. At the cathode, protons are reduced back to hydrogen gas (HER). The anode and cathode reactions, together with their standard electrode potentials are:

$$
\begin{array}{ll}
H_{2(g)} \rightarrow 2 H_{(a q)}^{+}+2 e^{-} & E^{\Theta}=0.0 \mathrm{~V} \text { vs. SHE } \\
2 H_{(a q)}^{+}+2 e^{-} \rightarrow H_{2(g)} & E^{\Theta}=0.0 \mathrm{~V} \text { vs. SHE }
\end{array}
$$


Since their standard potential values are the same when the gas pressure is equal at both sides of the membrane, the standard cell potential is $0.0 \mathrm{~V}$ :

$$
H_{2(g)} \rightarrow H_{2(g)} \quad U^{\Theta}=0.0 \mathrm{~V} \text { vs. SHE }
$$

Naturally, when current flows through the cell, activation and ohmic overpotentials take place. Of these, the resistive behaviour of the membrane dominates [27], due to the very low activation overpotential for the hydrogen reactions [28]. In effect, the overall cell reaction consists on the transfer of hydrogen from the anodic half-cell to the cathodic half-cell. When used for hydrogen compression, the MEA needs additional mechanical support to endure the differential pressure between the two half-cells [29].

The preparation of the MEAs is critical to the performance of PEMFCs and EHPs and one of the most relevant steps involves the application of the catalyst ink to the gas diffusion layer (GDL) [30]. Numerous methods exist for this purpose [31,32]. Brush painting, 'doctor blading' and spraying are common manual techniques, while roll coating, extrusion and sputtering, in addition to scaled-up doctor blading and spraying, are used for continuous industrial processes seeking high reproducibility. Ink spray is relatively simple and economical, being suitable for the production of reasonably homogeneous coatings [33]. So-called 'air-less' spray guns are usually recommended for coating large electrodes due to their good handling of viscous fluids [34]. However, airbrushes can be better suited for making smaller electrodes for laboratory use [34]. Two main types are available: suction-feed (or siphon-feed) and gravity-feed. The suction-feed airbrush is in some ways similar to an 'air-less' spray gun. Air flows around the nozzle, creating a negative pressure that draws the ink from its reservoir, breaking the surface tension and forming fine droplets. Higher air pressure is usually required. In contrast, the gravity-feed type airbrush can use a low-pressure air flow to propel the ink, which trickles 
into an internal mixing chamber before being atomised. In some gravity-feed airbrush models, air flows around the nozzle as well, but in an angle intended to shape the exiting cone of aerosol without causing significant negative pressure at the liquid line.

The effect of the type of airbrush used to spray the catalyst on the gas diffusion layer has not been discussed previously, despite its importance in practical settings such as in universities and during early technology development at companies, e.g., [24,34-38]. The present work compares both suction-feed and gravity-feed airbrushes during the assessment of a methodology for the production of reproducible laboratory MEAs. These are intended for the evaluation of two in-house developed catalysts: 1) a platinum deposited on a carbon support, PtPV3, and 2) a platinum-cobalt alloy deposited on a carbon support, Pt-Copv3. They are first evaluated in PEMFC mode in order to establish the suitability of the MEA preparation methodology and comparing them to the benchmark commercial catalyst Hi-Spec ${ }^{\circledR} 3000$ (PtHS) [32]. The catalysts are later assessed in EHP mode, aiming to demonstrate the use of the MEAs for the oxidation and reduction of hydrogen. It should be noted that the potentially cost-effective platinum-alloy catalysts have received limited attention in EHPs [37,39], despite the fact that the hydrogen reactions taking place are quite fast and could be accomplished efficiently with less active catalysts [28].

\section{Experimental section}

\subsection{Catalyst and ink preparation}

Platinum on carbon $20 \%$ wt., PtPv3, was synthesised following a proprietary precipitation method. Hexachloroplatinic acid hydrate is first dissolved in water. Vulcan XC-72R carbon (Cabot Corp.) is added to the vessel with vigorous stirring until full dispersion is 
achieved. The platinum salt is then reduced chemically, for instance, by sodium bisulphite at $\mathrm{pH}=5$ and $25^{\circ} \mathrm{C}[40]$. The catalyst is then filtered with the aid of a vacuum pump, washed with deionised water and dried in air at $100{ }^{\circ} \mathrm{C}$. Platinum-cobalt on carbon $20 \%$ $w t$. in a proportion of $1: 1$, Pt-Copv3, was produced by a modified method to that of Leontyev et al. [8]. In this case, hexachloroplatinic acid hydrate and cobalt chloride are dissolved in an ethylene glycol aqueous solution, which is then poured into a vigorously stirred dispersion of Vulcan carbon. Sodium borohydride is then added and the reaction is maintained at $\mathrm{pH}=10$ and $25^{\circ} \mathrm{C}$ until complete reduction of the metal salts occurs. The catalyst is filtered and washed in the same manner as PtPv3. In order to compare these catalysts to a known benchmark, Hi-Spec ${ }^{\circledR} 3000$ platinum on carbon, $\mathrm{Pt}_{\mathrm{HS}}, 20 \%$ wt. was sourced from a commercial supplier (Alfa Aesar, Thermo Fisher Scientific Inc.) and evaluated at the same conditions.

Inks with a total solid content of 5\% wt. versus liquid mass and a carbon-ionomer ratio of 1:1 wt. were prepared by mixing multiple batches of the following base composition: 50 $\mathrm{mg}$ of catalyst, $800 \mathrm{mg}$ of $\mathrm{Nafion}^{\circledR}$ perfluorinated resin solution $5 \%$ wt. with $15-20 \%$ water content (Merck KGaA) and an additional $950 \mathrm{mg}$ of solvent, which is $20 \% \mathrm{vol}$. 2 propanol (IPA) HPLC grade (Thermo Fisher Scientific Inc.) in deionised water. The components were transferred to a previously dried pear-shaped $20 \mathrm{~cm}^{3}$ flask, stirred in a vortex mixer (Cole-Parmer LLC) and placed in a XUBA3 ultrasonic bath (Grant Instruments Ltd.) for $60 \mathrm{~min}$. at $22^{\circ} \mathrm{C}$. During the sonication, the mixture was also stirred in the vortex mixer for $30 \mathrm{~s}$ every $15 \mathrm{~min}$. in order to eliminate agglomerations. Inks were used immediately after their preparation, being kept under stirring for up to $5 \mathrm{~h}$. 


\subsection{Manufacture of MEAs}

MEAs were prepared by the catalyst-coated gas diffusion media method, as illustrated in Fig. 2a) along the equipment employed. For this, the catalyst ink was sprayed onto 5.0 $\mathrm{cm} \times 5.0 \mathrm{~cm}$ pieces of a carbon paper Sigracet $^{\circledR} 29 \mathrm{BC}(\mathrm{SGL}$ Carbon SE) with a nominal thickness of $235 \mu \mathrm{m}$. This gas diffusion media has a 5\%wt. PTFE hydrophobic pretreatment and a microporous carbon layer on one side. The catalyst layer is applied on top of the pre-treated surface in order to avoid the underutilization of catalyst otherwise deposited in the interior of the carbon paper [33], and for better water management [41]. Before being coated, the substrate pieces were dried in air at $80{ }^{\circ} \mathrm{C}$ in an Heratherm ${ }^{\circledR}$ oven (Thermo Fisher Scientific Inc.) and weighted in a balance (Mettler-Toledo Inc.) to an accuracy of \pm 0.01 micrograms. A double-action, suction-feed airbrush with a $0.5 \mathrm{~mm}$ nozzle model HS-182 was used to produce reliable, reproducible catalyst layers. Nevertheless, as explained below, a gravity-feed airbrush with a $0.35 \mathrm{~mm}$ nozzle model AB-800 was also tested for contrast. As shown in Figs. 2b) and 2f), after sonication the ink was sprayed manually from a distance of approximately $15 \mathrm{~cm}$ from the vertical target, making repeated horizontal movements which changed direction outside the target area. During the procedure, a moisture trap/filter was fitted to the airbrush, while the 100 W air compressor $\left(\mathrm{WIZ}^{\circledR}\right.$, Clarke International Ltd.) was set to a pressure of $2 \mathrm{~kg} \mathrm{~cm}^{-2}$. The coated substrates were dried at $80{ }^{\circ} \mathrm{C}$ for $6 \mathrm{~min}$., enough to remove all the solvents, before being weighed and sprayed again as many times as necessary in order to achieve the desired catalyst loading, usually 4 or 5 times per $0.1 \mathrm{mg} \mathrm{cm}^{-2}$ of catalyst. A tolerance of $\pm 3 \%$ weight error was allowed. In all cases, the nominal loading on the GDL was 0.1 $\mathrm{mg} \mathrm{cm}-2$ and $0.3 \mathrm{mg} \mathrm{cm}^{-2}$ at the anode and the cathode, respectively. The first value is considered as a durable loading for MEAs used in PEMFCs [31] and PEM electrolysis [32] as prepared by spray methods, although loadings in the order of $0.01 \mathrm{mg} \mathrm{cm}^{-2}$ appear 
to be feasible in technical hydrogen compressors by appropriate manufacturing conditions [15]. The second, higher value is common for cathode loadings in laboratory-scale PEM cells [42]. The coated carbon paper was then cut into square pieces of $5 \mathrm{~cm}^{2}$. The airbrushes were cleaned thoroughly with IPA before and after spraying the ink.

The proton exchange membrane Nafion $115, \mathrm{~N}_{115}$, (Chemours Co.), was cut in pieces of $4.5 \mathrm{~cm} \times 4.5 \mathrm{~cm}$ and pre-treated by soaking in deionised water at $80{ }^{\circ} \mathrm{C}$ for $60 \mathrm{~min}$., followed by immersion in $1 \mathrm{~mol} \mathrm{dm}^{-3} \mathrm{H}_{2} \mathrm{SO}_{4} 96 \%$ wt. Suprapur ${ }^{\circledR}$ (Merck KGaA) at the same conditions. The membrane was then rinsed several times and left in deionised water at $80{ }^{\circ} \mathrm{C}$ for another $60 \mathrm{~min}$. The pieces were then held extended and dried overnight at $22{ }^{\circ} \mathrm{C}$ and ambient pressure. A water bath was used to heat the beakers and the boiling point was deliberately avoided in order to minimise damage to the membranes [43]. The MEAs were hot-pressed in a 6-tonne hydraulic press (MTI Corp.), shown in Fig. 2c), at $150{ }^{\circ} \mathrm{C}$ for $300 \mathrm{~s}$ at a pressure of $2.5 \mathrm{MPa}$, calculated directly from the force applied by the press and the GDL geometrical surface area. In order to guarantee the alignment of the GDLs on both sides of the membrane, and to obtain a compression of approx. $75 \%$ during the hot-pressing, a PTFE stencil within two aluminium plates was used. As shown in Fig. 2d), the stencil consisted of two $10.0 \mathrm{~cm} \times 10.0 \mathrm{~cm}$ PTFE sheets with a thickness of $170 \mu \mathrm{m}$ provided with centred holes for the GDLs, forming a 'sandwich' with the membrane. The $5 \mathrm{~mm}$-thick aluminium plates had the same size as the PTFE sheets, but had two inter-locking alignment pins, as shown in Fig. 2e). All PTFE pieces were made in a LS6840 PRO laser cutter (HPC Laser Ltd.), see Fig. 2g), and two of them were also placed between the MEAs and the aluminium plates. The MEAs were allowed to cool down for $15 \mathrm{~min}$. before being removed from the stencil. 


\subsection{Electrochemical characterization}

PEMFC and EHP experiments were carried out using a $5 \mathrm{~cm}^{2}$ unit cell (PaxiTech SAS), shown in Fig. 2h), with monopolar graphite flow fields and gold-coated current collectors, each bolt having a torque of $1.0 \mathrm{~N} \mathrm{~m}$. Laser-cut PTFE gaskets, with a thickness of 170 $\mu \mathrm{m}$, were placed between the MEA and the graphite plates in order to achieve a controlled compression of the GDLs and minimise gas leakages. Fuel cell temperature, gas humidity, gas flow rate and gas pressure were controlled using an FCT-150S fuel cell station (BioLogic SAS), shown in Fig. 2i). In addition to the two $300 \mathrm{~W}$ heating elements inserted into the cell, two $2000 \mathrm{~W}$ electric fan heaters (Igenix Ltd.) were placed so as to heat the stainless steel elbow fittings attached to the cell and uninsulated pipe sections in order to eliminate liquid water condensation at these points. The employed fuel was hydrogen N4,5 grade $99.995 \%$ purity with total hydrocarbons $\leq 2 \mathrm{ppm}$. Oxygen $99.96 \%$ purity or BTCA 74 certified air with $19.92 \% \mathrm{O}_{2}, \mathrm{CO} \leq 1 \mathrm{ppm}, \mathrm{CO}_{2} \leq 300 \mathrm{ppm}$ and total $\mathrm{NO}_{\mathrm{x}} \leq 0.1 \mathrm{ppm}$ were used as oxidant. Nitrogen $99.96 \%$ purity was used as purge gas. All gases were sourced from BOC Ltd.

The electrochemical measurements were performed using an Autolab ${ }^{\circledR}$ PGSTAT 302N potentiostat (Metrohm AG) coupled to a 20 A booster under fixed gas flow rates. The cathode was set as the working electrode, while the anode acted both as counter and reference electrode. In all cases, the cell temperature was set to $80 \pm 0.5^{\circ} \mathrm{C}$ and the gas lines and humidifiers to $78 \pm 0.5^{\circ} \mathrm{C}$, representing a relative humidity of $92.2 \%$. The MEAs were pre-conditioned for $60 \mathrm{~min}$. by applying a constant cell potential of $0.55 \mathrm{~V}$ prior to the operation as a fuel cell or $0.1 \mathrm{~V}$ as a hydrogen pump. The polarisation curves were obtained via chronopotentiometry, i.e., by applying increasing constant current steps of $60 \mathrm{~s}$ duration, after which the last cell potential value was taken. The current increased 
in steps of $0.1 \mathrm{~A}$ between $0.0 \mathrm{~A}$ and $0.5 \mathrm{~A}$, and in steps of $0.25 \mathrm{~A}$ between $0.5 \mathrm{~A}$ and up to $7.5 \mathrm{~A}$. The current sign was positive and negative in galvanic and electrolytic mode, respectively. Fuel cell experiments were stopped when the cell potential reached a value of $0.4 \mathrm{~V}$. In the case of the hydrogen pump, the cut-off condition was a sharp potential increase of more than $0.1 \mathrm{~V}$ in a single $60 \mathrm{~s}$ step. The area resistance was calculated from the slope of the resistive region of the polarization curves, between 0.2 and $0.4 \mathrm{~A} \mathrm{~cm}^{-2}$ for the PEMFCs and between 0.1 and $0.5 \mathrm{~A} \mathrm{~cm}^{-2}$ for the EHPs.

In fuel cell mode, hydrogen flow rate was $70 \mathrm{~cm}^{3} \min ^{-1}$ and $\mathrm{O}_{2}$ flow rate was $70 \mathrm{~cm}^{3}$ min. ${ }^{-1}$. When using air, the flow rate was $300 \mathrm{~cm}^{3} \min ^{-1}$. In the hydrogen pump mode, the two half-cells were supplied with hydrogen at $70 \mathrm{~cm}^{3} \mathrm{~min}^{-1}$, aiming to simulate the operation in recirculation configuration as found in full scale devices [44]. The experiments were performed under a back pressure of $100 \pm 1 \mathrm{kPa}(1 \mathrm{bar})$ in each halfcell. In order to ensure accuracy, all the reported results are the average of triplicate measurements performed with different MEAs.

\subsection{Imaging techniques}

Scanning electron microscopy (SEM) images of the surface of catalyst-coated GDL samples before being hot-pressed into MEAs were obtained using a field emission electron microscope LEO 1450VP (Carl Zeiss AG) at 20kV and at a working distance of $19 \mathrm{~mm}$. Their qualitative and semi-quantitative elemental composition was determined using energy dispersive spectrometry (EDS) in a X-Act $10 \mathrm{~mm}^{2}$ area Silicon Drift Detector (Oxford Instruments plc) coupled to the microscope using the AZtec Energy software v.3.3. The region of interest for the elemental analysis had dimensions of 3.40 $\mathrm{mm} \times 2.55 \mathrm{~mm}$; see the Supporting Information. 


\section{Results and discussion}

\subsection{Effect of airbrush type on the morphology of the catalyst layer}

The gravity-feed airbrush produces particles poorly connected to the substrate, as shown in Fig. 3a), reducing the effective utilisation of the PtHs catalyst and hindering the fusion of the catalyst layer with the PEM, which increases ionic resistance. The agglomerations of catalyst particles reach sizes up to approximately $250 \mu \mathrm{m}$. In contrast, and as shown in Fig. 3d), the vacuum-feed airbrush yields the typical 'cracked mudflat' surface result of solvent evaporation during baking observed in many PEMFC electrodes [45], [46]. Such different morphologies are the result of the operating principle of the airbrush. In the gravity-feed type, see Fig. 3b), a relatively large volume of air propels and atomises the catalyst ink, drying the aero-sol droplets rapidly. When they reach the surface, these dry particles cannot incorporate into the catalyst layer and, as a result, they form the lumps observed in the micrograph. However, by using a vacuum-feed airbrush, see Fig. 3e), the atomised droplets are allowed to travel in a wet state across the short distance between the nozzle and the catalyst layer. This makes possible their integration into a relatively homogenous, flat surface, enabling the subsequent hot-pressing step.

\subsection{Effect of airbrush type on the electrochemical performance}

For the same PtHS catalyst and operational conditions, MEAs evaluated as hydrogenoxygen PEMFCs display a clear difference. As shown in Fig. 4a), the gravity-feed airbrush results in a cell with significant resistive losses, reaching a potential of $0.45 \mathrm{~V}$ at the relatively low current density of $0.85 \mathrm{~A} \mathrm{~cm}^{-2}$. This represents a current density approximately $0.35 \mathrm{~A} \mathrm{~cm}^{-2}$ lower than that obtained when using the suction-feed airbrush for the cut-off potential, which is reached at $1.35 \mathrm{~A} \mathrm{~cm}^{-2}$. The resistive region of the polarisation curve corresponding to the gravity-feed airbrush displays a significantly 
steeper slope of $-0.401 \Omega \mathrm{cm}^{2}$, in contrast the one for the suction-feed airbrush, which is $-0.298 \Omega \mathrm{cm}^{2}$.

A similar behaviour is observed when PtHS catalyst MEAs are used as EHPs, as shown in Fig. 4b). For the gravity-feed airbrush cut-off overpotentials become the limiting factor, due to water transport limitations in the membrane [47], at a current density nearly $0.5 \mathrm{~A}$ $\mathrm{cm}^{-2}$ lower than those made with the suction-feed airbrush. The area resistance of the MEA made using the gravity-feed airbrush was $0.230 \Omega \mathrm{cm}^{2}$, in contrast to a lower value of $0.165 \Omega \mathrm{cm}^{2}$ obtained with the suction-feed airbrush. The error bars suggest that the gravity-feed spray method is also less reproducible.

The clear disparity in the behaviour of the MEAs prepared with different spray techniques is explained by the resulting surface morphology of the catalyst layer deposited on the GDL, which is disadvantageous in the case of the gravity-feed airbrush, as shown in Fig. 3a). In view of these results, the MEAs were prepared afterwards using only the suctionfeed airbrush, aiming to maximize their performance by having relatively smooth, cracked mudflat catalyst layers before hot-pressing, such as the one on Fig. 3d).

\subsection{Morphology and composition of catalyst layers produced with in-house catalysts}

Since the morphology of the catalyst layer produced by the spray has a direct influence on the performance of the MEAs [30], SEM micrographs were used to analyse the electrodes prepared with the Pths, PtPv3, and Pt-Copv3 catalysts. Fig. 5 presents surface images of the anode with a loading of $0.1 \mathrm{mg} \mathrm{cm}^{-2}$ and the cathode with a loading of 0.3 $\mathrm{mg} \mathrm{cm}{ }^{-2}$ before being hot-pressed onto the PEM. A cracked mudflat surface is observed again in the case of the $20 \%$ wt. platinum catalysts, PtHS and PtPv3, showing a similar 
appearance. The cracks are more numerous and smaller with the higher cathode loading of $0.3 \mathrm{mg} \mathrm{cm}^{-2}$. As the drying time in the oven at $80{ }^{\circ} \mathrm{C}$ was the same as in the loading of $0.1 \mathrm{mg} \mathrm{cm}^{-2}$, it is likely that these platinum catalysts loose solvent faster when forming part of a relatively thick coating [32]. On the other hand, the surface of the Pt-Copv3 catalyst is different than those containing only platinum. At a loading of $0.1 \mathrm{mg} \mathrm{cm}$, some cracks are visible, but roughness is slightly increased. When reaching a loading of $0.3 \mathrm{mg} \mathrm{cm}{ }^{-2}$, particles with sizes up to approximately $50 \mu \mathrm{m}$ in average lie over the cracked surface, although being significantly smaller than the ones observed with the gravity-feed airbrush; compare to Fig. 3a). The Pt-Copv3 catalyst ink was prepared, sprayed and dried in the same manner as the pure platinum catalysts, having the same total metal $\% w t$. ratio in respect to carbon. It is likely that cobalt has a different affinity towards the steric hindrance and high negative charge of the Nafion dispersion [48], modifying the size of the aggregates and the rheological properties of the ink. A diminished hydrophilicity due to the presence of cobalt could also prompt a faster solvent loss in the aero-sol. As seen below, the presence of particles in the Pt-Copvz catalyst layer will have an impact on their performance in the cells.

The semi-quantitative EDS elemental compositions of the catalyst layers made with the three evaluated catalysts are shown in Table 1 for a loading of $0.1 \mathrm{mg} \mathrm{cm}^{-2}$ and in Table 2 for a loading of $0.3 \mathrm{mg} \mathrm{cm}^{-2}$. As expected, both cases display similar relative weight compositions, in consistency with the reproducibility of the polarization curves. The apparent carbon content is the maximum when using the PtHs catalyst, followed by PtCopv3 and Ptpv3 types. Meanwhile, the apparent platinum content is slightly higher at the PtHS catalyst over the PtPv3 catalyst layer. The presence of fluorine and sulphur is due to the Nafion ionomer. Traces of copper $<0.06 \%$ in relative atomic percentage were found 
in Pths and PtPv3 catalyst layers for the low loading and in all the catalyst layers in the high loading case. This is likely a consequence of using brass airbrush nozzles and could be prevented with the use of high-quality stainless steel nozzles. The presence of copper up to an atomic ratio of 3.3/96.7 to platinum has no significant effect on MEAs with catalyst loadings of $0.1 \mathrm{mg} \mathrm{cm}^{-2}$ [49]. Elemental mapping indicates a uniform dispersion and composition of the catalyst ink layer in all cases. The qualitative composition of all catalysts is also confirmed. EDS spectra and elemental mapping images are supplied in the Supporting Information.

\subsection{Performance of in-house developed catalysts in fuel cell mode}

Polarisation and power density curves for each of the three catalysts as obtained using pure $\mathrm{O}_{2}$ as the oxidant are presented in Fig. 6 and Table 3. The main observable feature is the similar behaviour of the two platinum-carbon catalysts, $\mathrm{Pt}_{\mathrm{HS}}$ and PtPv3. These catalysts develop a cell potential of $0.6 \mathrm{~V}$ at $0.82 \mathrm{~A} \mathrm{~cm}^{-2}$. The only significant difference occurs over a current density of $1.2 \mathrm{~A} \mathrm{~cm}^{-2}$, in the current density range, where the onset of mass transport limitations takes place for the ORR. Here, the Ptpv3 catalyst appears to have a slight advantage owing, possibly, to a smaller particle size or a higher degree of dispersion. The power density curve shows the same trend.

The maximum current density and power in Fig. 6 are superior than those for an MEA having an identical Nafion 115 membrane but a higher, symmetrical catalyst loading of $0.4 \mathrm{mg} \mathrm{cm}^{-2}$ at commercial electrodes (E-TEK Inc.) operating under the same pure $\mathrm{O}_{2}$ and $80{ }^{\circ} \mathrm{C}$ but at gas pressures 3 times higher $(304 \mathrm{kPa})$ [50]. That MEA affords practically the same $0.80 \mathrm{~A} \mathrm{~cm}^{-2}$ at the typical operational voltage of $0.6 \mathrm{~V}$, although it reaches mass transport limitations beyond $1.75 \mathrm{~A} \mathrm{~cm}^{-2}$ because of the greater pressure. Notably, the 
results shown in Fig. 6 are also an improvement over those obtained with an MEA in which an airbrush was used to apply the catalyst layer from a similar ink composition containing an EC-20PTC 20\% wt. Pt catalyst (Electrochem Inc.) nominally equivalent to Hi-Spec 3000 [35]. Despite using ultra-high purity $\mathrm{O}_{2}$ at $80{ }^{\circ} \mathrm{C}$ and gas pressures nearly 4 times higher (404 $\mathrm{kPa})$ it appears that the use of thicker Nafion $117(183 \mu \mathrm{m})$ resulted in more resistive losses in that work, causing mass transport limitations to onset at approximately $0.7 \mathrm{~A} \mathrm{~cm}^{-2}$. However, the catalyst layer morphology and type of airbrush were not reported, being possibly behind the observed additional resistance. As expected, our results display a lower performance than MEAs in which the catalyst ink was sprayed directly on Nafion 212 instead of on the GDL [51], which sustained $0.6 \mathrm{~V}$ at $1.4 \mathrm{~A} \mathrm{~cm}^{-2}$. Using Nafion 212 also reduces the overall resistance due to a smaller thickness (51 $\mu \mathrm{m}$ compared to the $127 \mu \mathrm{m}$ of the Nafion 115 used in the present work). Another MEA with better tolerance to polarization used an Asahi Aciplex ${ }^{\circledR}$ S-1104 membrane and a catalyst loading of $0.2 \mathrm{mg} \mathrm{cm}^{-2}$, producing $0.6 \mathrm{~V}$ at $1.8 \mathrm{~A} \mathrm{~cm}^{-2}$ [33]. Albeit having a $100 \mu \mathrm{m}$-thick membrane, this cell operated at a pressure of $506 \mathrm{kPa}$ and a temperature of $95^{\circ} \mathrm{C}$.

Regarding the Pt-Copv3 catalyst under pure $\mathrm{O}_{2}$, it underperforms compared to the platinum-only catalysts, achieving $0.60 \mathrm{~A} \mathrm{~cm}^{-2}$ at $0.6 \mathrm{~V}$ and displaying a more resistive polarisation curve. In a similar way as in the gravity-fed airbrush, see Fig. 3a), the particles present in the resulting catalyst layer containing Pt-Copv3, see Fig. 5f), interfere negatively with the performance of the MEA by increasing resistance of the catalystmembrane interphase and inducing catalyst under-utilisation. This implies that the observed performance of the Pt-Copv3 catalyst layer was determined by the combined increased resistive behaviour and by the inherently slower reaction kinetics towards the hydrogen reactions. Further work is hence needed to determine the contribution of 
reaction kinetics at Pt-Co alloy catalysts in adequate conditions [28,52]. From a practical point of view, an evaluation of different ratios of Pt-Co, carbon, Nafion ionomer and the components of the solvent mixture could lead to an improved ink rheology that facilitates the formation of cracked-mud deposits instead [48].

When the cell employs air as the oxidant, the overall results are analogous. $\mathrm{Pt}_{\mathrm{HS}}$ and $\mathrm{P} \mathrm{t}_{\mathrm{PV}}$ catalysts behave to a higher degree of similarity, being indistinguishable from each other. As shown in Fig. 7, they both yield a current density of $0.64 \mathrm{~A} \mathrm{~cm}^{-2}$ at $0.6 \mathrm{~V}$ whereas the Pt-Copv3 catalyst reaches the same potential at $0.44 \mathrm{~A} \mathrm{~cm}^{-2}$, being more resistive for the reasons mentioned in section 3.2. As shown in Table 3, the open circuit cell voltage is expectedly lower than when using pure $\mathrm{O}_{2}$. Additionally, the enhanced mass transport limitations imply that the platinum catalysts reach the cut-off potential of $0.4 \mathrm{~V}$ at a current density approximately $0.3 \mathrm{~A} \mathrm{~cm}^{-2}$ lower than when using pure $\mathrm{O}_{2}$. These results display a performance comparable to a PEM fuel cell using carbon cloth as GDL and Nafion 112 (thickness $51 \mu \mathrm{m}$ ) at similar temperature and pressure [53], in which the platinum catalyst loading at the cathode was up to $0.33 \mathrm{mg} \mathrm{cm}^{-2}$. They are also similar to the polarisation curves obtained by spraying the catalyst into a Nafion HP membrane (thickness $20.3 \mu \mathrm{m}$ ) using an ultrasonic nozzle and the same loading [42], especially when comparing the hot-pressed MEAs. Again, the PEMFC with Aciplex S-1104 membrane and sprayed platinum catalyst afforded a higher current density of $1.15 \mathrm{~A} \mathrm{~cm}^{-2}$ for a cell voltage of $0.6 \mathrm{~V}$ under air at $70{ }^{\circ} \mathrm{C}[33]$, at the cost of operating at a pressure of $506 \mathrm{kPa}$.

\subsection{Performance of in-house developed catalysts electrochemical hydrogen pump mode}

In the polarisation curves for the EHP cell, the reactions of interest are the oxidation of hydrogen gas and reduction of protons. The anode and cathode catalyst loadings were 
kept the same as in the PEMFC electrodes, for consistency in our methodology, although symmetric loadings are more common in hydrogen pumps. The lower loading at the anode is not expected to be limiting the performance, as the transport of protons through the membrane is the slowest step in the overall cell reaction [27]. The polarisation curves for each catalyst are shown in Fig. 8 and the measured operational parameters are given in Table 3. Practically equal results are given by $\mathrm{Pt}_{\mathrm{HS}}$ and Ptpv3 catalysts, but the latter appears to have a marginal capacity for decreasing the overpotential, albeit within the range of experimental error. The slope for the pure resistive section of the curve has a value of $0.165 \Omega \mathrm{cm}^{2}$ and $0.161 \Omega \mathrm{cm}^{2}$, respectively, reinforcing the fact that proton transport at the membrane is the rate controlling step.

Commercial research and development of electrochemical hydrogen compression and purification aims to operate at a maximum overpotential of $250 \mathrm{mV}$ at a current density of $1 \mathrm{~A} \mathrm{~cm}^{-2}$ for 350 bar applications [29]. Meanwhile, the PtPv3 and its benchmark yield an overpotential of $185 \mathrm{mV}$ at the same current density of $1 \mathrm{~A} \mathrm{~cm}^{-2}$, suggesting a relative degree of technological readiness for technical devices, being similar to a prototype hydrogen compressor sustaining an outlet pressure of 20 bar at the same temperature [29]. Both catalysts compared favourable against a hydrogen pump with a thicker Nafion 117 membrane $(183 \mu \mathrm{m})$, and hence a larger resistivity, which generated an overpotential of approximately $360 \mathrm{mV}$ at $1 \mathrm{~A} \mathrm{~cm}^{-2}$ and $75^{\circ} \mathrm{C}$ [54], despite having a symmetrical catalyst loading of $0.4 \mathrm{mg} \mathrm{cm}^{-2}$, which is 4 times more than in this work at the anode.

In a similar way as in PEMFC mode, the MEA containing the Pt-Copv3 catalyst displayed higher overpotentials in EHP mode, $200 \mathrm{mV}$ at a current density of $0.8 \mathrm{~A} \mathrm{~cm}^{-2}$, and a slope value of $0.217 \Omega \mathrm{cm}^{2}$; see Table 3. Still, if the quality of the Pt-Copv3 catalyst layer 
deposited on the GDL, Fig. 5f), was improved, the overpotential could decrease down to levels closer to the pure platinum catalysts. This might be achieved by screening a range of solvent mixtures and solid to liquid ratio in the ink containing the Pt-Co catalyst [48].

\section{Conclusion and future work}

It was found that the 'air-less' suction-feed airbrush is preferable for spraying catalyst ink over the gravity-feed type because it produces a smoother, more homogeneous catalyst layer and a 'crack-mud' surface morphology. These features permit to produce a better MEA after the hot-pressing step, resulting in a superior electrochemical performance. The gravity-feed airbrush produces loose particle deposits, which reduce catalyst utilisation and increase the resistance of the MEA. Stainless steel airbrush nozzles are recommended in order to diminish the possibility of contamination in the ink.

The in-house developed 20\% wt. PtPV3 catalyst performed as well as HiSpec-3000, suggesting that an adequate dispersion of the catalyst was achieved during its preparation. As a result, the PtPv3 catalyst has the potential to be employed in PEMFCs as well as in electrochemical hydrogen compression and purification devices. In comparison, the PtCopv3 alloy catalyst displayed a poor performance, most likely because the surface morphology of the catalyst layer prepared with it differed from those obtained with the other catalysts. The presence of cobalt appears to modify the rheology of the ink in such a way that more loose particles are produced during the spray step, resulting in a more resistive behaviour due to poor contact with the PEM. However, more fundamental catalyst studies are required to assess the role of Pt-Co reaction kinetics. Further optimization of the composition of the cobalt-containing ink is needed to make it suitable for spray with standard airbrushes. 


\section{Conflict of interest statement}

The authors declare that there is no conflict of interests.

\section{Acknowledgements}

The authors acknowledge the financial support of the Technology Strategy Board: Newton Fund UK-Mexico Collaborative Industrial R\&D Programme [grant number 69759- 450305]. LFA is thankful to Prof J. E. Graves from Coventry University for his helpful comments on the nozzles of airbrushes.

\section{References}

[1] The Roadmap Report. Towards 2040: A Guide to Automotive Propulsion Technologies, Advanced Propulsion Centre UK \& Automotive Council UK, 2018. https://www.apcuk.co.uk/ roadmap-report/.

[2] D.-Y. Lee, A. Elgowainy, A. Kotz, R. Vijayagopal, J. Marcinkoski, Life-cycle implications of hydrogen fuel cell electric vehicle technology for medium- and heavy-duty trucks, J. Power Sources. 393 (2018) 217-229. doi:10.1016/j.jpowsour.2018.05.012.

[3] M. Voldsund, K. Jordal, R. Anantharaman, Hydrogen production with $\mathrm{CO}_{2}$ capture, Int. J. Hydrogen Energy. 41 (2016) 4969-4992. doi:10.1016/j.ijhydene.2016.01.009.

[4] W. Sheng, H.A. Gasteiger, Y. Shao-Horn, Hydrogen oxidation and evolution reaction reaction kinetics on platinum: Acid vs alkaline electrolytes, J. Electrochem. Soc. 157 (2010) B1529-B1536. doi:10.1149/1.3483106.

[5] L. Xing, W. Shi, H. Su, Q. Xu, P.K. Das, B. Mao, et al., Membrane electrode assemblies for PEM fuel cells: A review of functional graded design and optimization, Energy. 177 (2019) 445-464. doi:10.1016/j.energy.2019.04.084.

[6] O.T. Holton, J.W. Stevenson, The role of platinum in proton exchange membrane fuel cells, Platinum Metals Rev. 57 (2013) 259-271. doi:10.1595/147106713X671222.

[7] Y. Bing, H. Liu, L. Zhang, D. Ghosh, J. Zhang, Nanostructured Pt-alloy electrocatalysts for PEM fuel cell oxygen reduction reaction, Chem. Soc. Rev. 39 (2010) 2184-19. doi:10.1039/b912552c. 
[8] I.N. Leontyev, V.E. Guterman, E.B. Pakhomova, P.E. Timoshenko, A V Guterman, I.N. Zakharchenko, et al., XRD and electrochemical investigation of particle size effects in platinum-cobalt cathode electrocatalysts for oxygen reduction, J. Alloys Compd. $500 \quad$ (2010) 241-246. doi:10.1016/j.jallcom.2010.04.018.

[9] M. Li, Y. Lei, N. Sheng, T. Ohtsuka, Preparation of low-platinum-content platinum-nickel, platinum-cobalt binary alloy and platinum-nickel-cobalt ternary alloy catalysts for oxygen reduction reaction in polymer electrolyte fuel cells, J. Power Sources. 294 (2015) 420-429. doi:10.1016/j.jpowsour.2015.06.084.

[10] M. Millán, H. Zamora, M.A. Rodrigo, J. Lobato, Enhancement of electrode stability using platinum-cobalt nanocrystals on a novel composite SiCTiC support, ACS Appl. Mater. Interfaces. 9 (2017) 5927-5936. doi:10.1021/acsami.6b13071.

[11] G.A. Attard, J.-Y. Ye, A. Brew, D. Morgan, P. Bergstrom-Mann, S.-G. Sun, Characterisation and electrocatalytic activity of PtNi alloys on $\mathrm{Pt}\{111\}$ electrodes formed using different thermal treatments, J. Electroanal. Chem. 716 (2014) 106111. doi:10.1016/j.jelechem.2013.09.018.

[12] X. Peng, S. Zhao, T.J. Omasta, J.M. Roller, W.E. Mustain, Activity and durability of Pt-Ni nanocage electocatalysts in proton exchange membrane fuel cells, App. Catal. B: Environ. 203 (2017) 927-935. doi:10.1016/j.apcatb.2016.10.081.

[13] P. Bouwman, Electrochemical Hydrogen Compression (EHC) solutions for hydrogen infrastructure, Fuel Cells Bulletin. 2014 (2014) 12-16. doi:10.1016/S1464-2859(14)70149-X.

[14] J.M. Sedlak, J.F. Austin, A.B. LaConti, Hydrogen recovery and purification using the solid polymer electrolyte electrolysis cell, Int. J. Hydrogen Energy. 6 (1981) 45-51. doi:10.1016/0360-3199(81)90096-3.

[15] P. Bouwman, Fundamentals of Electrochemical Hydrogen Compression, in: D. Bessarabov, H. Wang, H. Li, N. Zhao (Eds.), PEM Electrolysis for Hydrogen Production, CRC Press, Boca Raton, 2015: pp. 269-302. doi:10.1201/b19096-14.

[16] M. Suermann, T. Kiupel, T.J. Schmidt, F.N. Büchi, Electrochemical hydrogen compression: Efficient pressurization concept derived from an energetic evaluation, J. Electrochem. Soc. $164 \quad$ (2017) F1187-F1195. doi:10.1149/2.1361712jes.

[17] ISO 14687-1:1999. Hydrogen fuel - Product specification - Part 1: All applications except proton exchange membrane (PEM) fuel cell for road vehicles, 1999. 
[18] B. Bahar, W. Parmelee, S. Fackler, R. Sherrer, J. Zerby, O. Abdelaziz, et al., An overview of advancements in electrochemical compressor driven heat pump systems, in: Rotterdam, 2017.

[19] T.M. Molter, W.F. Smith, Electrochemical gas purifier, US Patent 6,168,705 B1, 2001.

[20] J.S. Preston, T.M. Molter, K.E. Murdoch, M.B. Abney, Z. Greenwood, Electrolyte membrane hydrogen recovery for advanced oxygen recovery architecture, in: Bellevue, Washington, 2015: pp. 1-14.

[21] Helium recovery system based on high-performance proton exchange membranes, Phase I, NASA, 2015. https://techport.nasa.gov/view/33826.

[22] B. Ibeh, C. Gardner, M. Ternan, Separation of hydrogen from a hydrogen/methane mixture using a PEM fuel cell, Int. J. Hydrogen Energy. 32 (2007) 908-914.

[23] R. Doucet, C. Gardner, M. Ternan, Separation of hydrogen from hydrogen/ethylene mixtures using PEM fuel cell technology, Int. J. Hydrogen Energy. 34 (2009) 998-1007.

[24] X. Wu, G. He, L. Yu, X. Li, Electrochemical hydrogen pump with SPEEK/CrPSSA semi-interpenetrating polymer network proton exchange membrane for H2/CO2 separation, ACS Sustainable Chem. Eng. 2 (2013) 75-79. doi:10.1021/sc400329s.

[25] R. Chen, R. Fan, H.H. Duong, C.R.I. Chisholm, I.W. Kaye, Integrated methanol steam reformer/electrochemical hydrogen compressor, ECS Trans. 58 (2013) $175-181$.

[26] M. Carmo, D.L. Fritz, J. Mergel, D. Stolten, A comprehensive review on PEM water electrolysis, Int. J. Hydrogen Energy. 38 (2013) 4901-4934. doi:10.1016/j.ijhydene.2013.01.151.

[27] A. Huth, B. Schaar, T. Oekermann, A "proton pump" concept for the investigation of proton transport and anode kinetics in proton exchange membrane fuel cells, Electrochim. Acta. 54 (2009) 2774-2780. doi:10.1016/j.electacta.2008.11.010.

[28] J. Durst, C. Simon, F. Hasché, H.A. Gasteiger, Hydrogen oxidation and evolution reaction kinetics on carbon supported $\mathrm{Pt}, \mathrm{Ir}, \mathrm{Rh}$, and $\mathrm{Pd}$ electrocatalysts in acidic media, J. Electrochem. Soc. 162 (2015) F190-F203. doi:10.1149/2.0981501jes.

[29] M. Hamdan, Electrochemical Compression. 2018 Hydrogen and Fuel Cells Program. Annual Merit Review Meeting., Giner ELX, Inc, 2018. https://www.hydrogen.energy.gov/pdfs/review18/pd136_hamdan_2018_o.pdf. 
[30] S. Litster, G. McLean, PEM fuel cell electrodes, J. Power Sources. 130 (2004) 6176. doi:10.1016/j.jpowsour.2003.12.055.

[31] B. Koraishy, J.P. Meyers, K.L. Wood, Manufacturing of membrane electrode assemblies for fuel cells, in: 7th International Conference on Manufacturing Research (ICMR 2009), Warwick, 2009: pp. 1-13.

[32] B. Bladergroen, H. Su, S. Pasupathi, V. Linkov, Overview of membrane electrode assembly preparation methods for solid polymer electrolyte electrolyzer, in: J. Kepleris (Ed.), Electrolysis, InTech, 2012: pp. 45-60. doi:10.5772/52947.

[33] R. Mosdale, M. Wakizoe, S. Srinivasan, Fabrication of electrodes for proton exchange membrane fuel cells using a spraying method and their performance evaluation, in: S. Srinivasan, D.D. Macdonald, A.C. Khandkar (Eds.), Proceedings of the Symposium on Electrode Materials and Processes for Energy Conversion and Storage, Pennington, 1994: pp. 179-189.

[34] S. Sarangapani, F.J. Luczak, Experimental methods in low temperature fuel cells, in: Fuel Cells: From Fundamentals to Applications, Springer, 2006.

[35] A. Barrio, J. Parrondo, J.I. Lombraña, M. Uresandi, F. Mijangos, Influence of manufacturing parameters on MEA and PEMFC performance, Int. J. Chem. React. Eng. 6 (2008) Article A26.

[36] A. Abdulla, K. Laney, M. Padilla, S. Sundaresan, J. Benziger, Efficiency of hydrogen recovery from reformate with a polymer electrolyte hydrogen pump, AIChE J. 57 (2011) 1767-1779. doi:10.1002/aic.12406.

[37] X. Wu, J. Benziger, G. He, Comparison of Pt and Pd catalysts for hydrogen pump separation from reformate, J. Power Sources. 218 (2012) 424-434.

[38] U. Rost, P. Podleschny, M. Schumacher, R. Muntean, D.T. Pascal, C. Mutascu, et al., Long-term stable electrodes based on platinum electrocatalysts supported on titanium sintered felt for the use in PEM fuel cells, IOP Conf. Ser.: Mater. Sci. Eng. 416 (2018) 012013. doi:10.1088/1757-899X/416/1/012013.

[39] A. Tokarev, D. Bessarabov, Modeling of bimetallic Pt-based electrocatalyst on extended-surface support for advanced hydrogen compression and separation, Int. J. Hydrogen Energy. 39 (2014) 7805-7810. doi:10.1016/j.ijhydene.2014.03.138.

[40] M. Watanabe, M. Uchida, S. Motoo, Preparation of highly dispersed Pt $+\mathrm{Ru}$ alloy clusters and the activity for the electrooxidation of methanol, Fuel Process. Technol. 229 (1987) 395-406. doi:10.1016/0022-0728(87)85156-2. 
[41] S. Park, J.-W. Lee, B.N. Popov, Effect of carbon loading in microporous layer on PEM fuel cell performance, J. Power Sources. 163 (2006) 357-363. doi:10.1016/j.jpowsour.2006.09.020.

[42] M.B. Sassin, Y. Garsany, B.D. Gould, K.E. Swider-Lyons, Fabrication method for laboratory-scale high-performance membrane electrode assemblies for fuel cells, Anal. Chem. 89 (2016) 511-518. doi:10.1021/acs.analchem.6b03005.

[43] M.C. Tucker, A. Weiss, A.Z. Weber, Cerium-hydrogen redox flow cell optimization, ECS Meet. Abstr. MA2016-01 (2016) 379-379.

[44] F. Barbir, B. Balasubramanian, M. Stone, Electrochemical hydrogen compressor for electrochemical cell system and method for controlling, 2006.

[45] A. Pokhrel, M. El Hannach, F.P. Orfino, M. Dutta, E. Kjeang, Failure analysis of fuel cell electrodes using three-dimensional multi-length scale X-ray computed tomography, J. Power Sources. $329 \quad$ (2016) 330-338. doi:10.1016/j.jpowsour.2016.08.092.

[46] Q. Meyer, N. Mansor, F. Iacoviello, P.L. Cullen, R. Jervis, D. Finegan, et al., Investigation of hot pressed polymer electrolyte fuel cell assemblies via X-ray computed tomography, Electrochim. Acta. 242 (2017) 125-136. doi:10.1016/j.electacta.2017.05.028.

[47] Y. Hao, H. Nakajima, H. Yoshizumi, A. Inada, K. Sasaki, K. Ito, Characterization of an electrochemical hydrogen pump with internal humidifier and dead-end anode channel, Int. J. Hydrogen Energy. 41 (2016) 13879-13887. doi:10.1016/j.ijhydene.2016.05.160.

[48] T.T. Ngo, T.L. Yu, H.-L. Lin, Influence of the composition of isopropyl alcohol/water mixture solvents in catalyst ink solutions on proton exchange membrane fuel cell performance, J. Power Sources. 225 (2013) 293-303. doi:10.1016/j.jpowsour.2012.10.055.

[49] Z.D. Wei, Y.C. Feng, L. Li, M.J. Liao, Y. Fu, C.X. Sun, et al., Electrochemically synthesized $\mathrm{Cu} / \mathrm{Pt}$ core-shell catalysts on a porous carbon electrode for polymer electrolyte membrane fuel cells, J. Power Sources. 180 (2008) 84-91. doi:10.1016/j.jpowsour.2008.01.086.

[50] K.T. Adjemian, S.J. Lee, S. Srinivasan, J. Benziger, A.B. Bocarsly, Silicon oxide Nafion composite membranes for proton-exchange membrane fuel cell operation at $80-140^{\circ}$ C, J. Electrochem. Soc. 149 (2002) A256-6. doi:10.1149/1.1445431.

[51] X. Peng, T. Omasta, W. Rigdon, W.E. Mustain, Fabrication of high performing PEMFC catalyst-coated membranes with a low cost air-assisted cylindrical liquid 
jets spraying system, J. Electrochem. Soc. 163 (2016) E407-E413. doi:10.1149/2.0981614jes.

[52] F. Capitanio, S. Siracusano, A. Stassi, V. Baglio, A.S. Aricò, A.C. Tavares, AC impedance spectroscopy investigation of carbon supported $\mathrm{Pt}_{3} \mathrm{Co}$ and $\mathrm{Pt}$ cathode catalysts in direct methanol fuel cell, Int. J. Hydrogen Energy. 39 (2014) 80268033 .

[53] Z. Qi, A. Kaufman, Low Pt loading high performance cathodes for PEM fuel cells, J. Power Sources. 113 (2003) 37-43. doi:10.1016/S0378-7753(02)00477-9.

[54] S.A. Grigoriev, I.G. Shtatniy, P. Millet, V.I. Porembsky, V.N. Fateev, Description and characterization of an electrochemical hydrogen compressor/concentrator based on solid polymer electrolyte technology, Int. J. Hydrogen Energy. 36 (2011) 4148-4155. doi:10.1016/j.ijhydene.2010.07.012. 


\section{$\underline{\text { Tables }}$}

Table 1. EDS semi-quantitative composition analysis of the evaluated catalyst layers with a loading of $0.1 \mathrm{mg} \mathrm{cm}^{-2}$ as sprayed with a suction-feed airbrush on carbon paper. The data shows the normalised concentration in weight percent, the weight percent error (1 sigma) and the atomic weight percent.

\begin{tabular}{|c|c|c|c|c|c|c|c|c|c|c|c|}
\hline \multicolumn{4}{|c|}{ Pths catalyst layer } & \multicolumn{4}{|c|}{ PtPv3 catalyst layer } & \multicolumn{4}{|c|}{ Pt-Copv3 catalyst layer } \\
\hline Element & Wt. \% & Wt. \% error & Atomic \% & Element & Wt. \% & Wt. \% error & Atomic \% & Element & Wt. \% & Wt. \% error & Atomic \% \\
\hline $\mathrm{C}$ & 62.43 & 0.24 & 78.68 & $\mathrm{C}$ & 54.64 & 0.22 & 70.75 & $\mathrm{C}$ & 58.29 & 0.23 & 72.14 \\
\hline $\mathrm{F}$ & 20.53 & 0.19 & 16.35 & $\mathrm{~F}$ & 28.25 & 0.19 & 23.13 & $\mathrm{~F}$ & 28.82 & 0.20 & 22.55 \\
\hline $\mathrm{Pt}$ & 11.86 & 0.15 & 0.92 & $\mathrm{Pt}$ & 10.62 & 0.13 & 0.85 & $\mathrm{Pt}$ & 5.99 & 0.12 & 0.46 \\
\hline $\mathrm{O}$ & 3.55 & 0.15 & 3.35 & $\mathrm{O}$ & 4.56 & 0.13 & 4.44 & $\mathrm{O}$ & 4.24 & 0.14 & 3.94 \\
\hline $\mathrm{S}$ & 1.25 & 0.03 & 0.59 & $\mathrm{~S}$ & 1.39 & 0.03 & 0.68 & $\mathrm{~S}$ & 1.13 & 0.03 & 0.52 \\
\hline $\mathrm{Cu}$ & 0.30 & 0.06 & 0.07 & $\mathrm{Cu}$ & 0.37 & 0.05 & 0.09 & $\mathrm{Co}$ & 1.53 & 0.05 & 0.39 \\
\hline $\mathrm{Cl}$ & 0.09 & 0.02 & 0.04 & $\mathrm{Cl}$ & 0.17 & 0.02 & 0.07 & Total & 100 & & 100 \\
\hline Total & 100 & & 100 & Total & 100 & & 100 & & & & \\
\hline
\end{tabular}


Table 2. EDS semi-quantitative composition analysis of the evaluated catalyst layers with a loading of $0.3 \mathrm{mg} \mathrm{cm}^{-2}$ as sprayed with a suction-feed

\begin{tabular}{|c|c|c|c|c|c|c|c|c|c|c|c|}
\hline \multicolumn{4}{|c|}{ PthS catalyst layer } & \multicolumn{4}{|c|}{ Ptpv3 catalyst layer } & \multicolumn{4}{|c|}{ Pt-Copv3 catalyst layer } \\
\hline Element & Wt. \% & Wt. \% error & Atomic \% & Element & Wt. $\%$ & Wt. \% error & Atomic \% & Element & wt. \% & Wt. \% error & Atomic \% \\
\hline $\mathrm{C}$ & 58.30 & 0.25 & 74.56 & $\mathrm{C}$ & 51.63 & 0.26 & 67.93 & $\mathrm{C}$ & 58.28 & 0.25 & 72.79 \\
\hline $\mathrm{F}$ & 24.61 & 0.20 & 19.9 & $\mathrm{~F}$ & 31.15 & 0.23 & 25.91 & $\mathrm{~F}$ & 27.46 & 0.21 & 21.68 \\
\hline $\mathrm{Pt}$ & 11.37 & 0.15 & 0.90 & $\mathrm{Pt}$ & 10.72 & 0.15 & 0.87 & $\mathrm{Pt}$ & 6.66 & 0.13 & 0.51 \\
\hline $\mathrm{O}$ & 4.07 & 0.15 & 3.91 & $\mathrm{O}$ & 4.39 & 0.15 & 4.34 & $\mathrm{O}$ & 4.13 & 0.15 & 3.88 \\
\hline S & 1.34 & 0.03 & 0.64 & S & 1.49 & 0.03 & 0.74 & S & 1.24 & 0.03 & 0.58 \\
\hline $\mathrm{Cu}$ & 0.23 & 0.06 & 0.06 & $\mathrm{Cu}$ & 0.20 & 0.06 & 0.05 & Co & 2.00 & 0.06 & 0.51 \\
\hline $\mathrm{Cl}$ & 0.07 & 0.02 & 0.03 & $\mathrm{Cl}$ & 0.26 & 0.02 & 0.12 & $\mathrm{Cu}$ & 0.21 & 0.06 & 0.05 \\
\hline \multirow[t]{2}{*}{ Total } & 100 & & 100 & $\mathrm{Fe}$ & 0.15 & 0.04 & 0.04 & Total & 100 & & 100 \\
\hline & & & & Total & 100 & & 100 & & & & \\
\hline
\end{tabular}

airbrush on carbon paper. The data shows the normalised concentration in weight percent, the weight percent error (1 sigma) and the atomic weight percent. 
Table 3. Measured operational parameters of MEAs prepared with PtHS, PtPv3, and Pt-Copv3 catalysts in PEMFC and EHP modes. The catalyst layer was applied using a suction-feed airbrush in all cases. Experimental conditions are those reported in Fig. 6, 7 and 8. The maximum current density, $j_{\max }$, is the value of the constant current density step at which the cell voltage reaches the minimum safe value of $0.4 \mathrm{~V}$ in a PEMFC during

\begin{tabular}{|c|c|c|c|c|c|c|c|c|c|}
\hline \multicolumn{4}{|c|}{ PEMFC mode, $\mathrm{H}_{2} / \mathrm{O}_{2}$} & \multicolumn{3}{|c|}{ PEMFC mode, $\mathrm{H}_{2} /$ air } & \multicolumn{3}{|c|}{ EHP mode, $\mathrm{H}_{2} / \mathrm{H}_{2}$} \\
\hline Catalyst & $\begin{array}{c}\text { Open circuit } \\
\text { voltage, } U_{0}, V\end{array}$ & $\begin{array}{c}\text { Max. current } \\
\text { density, } \boldsymbol{j}_{\text {max. }}, \mathrm{A} \\
\mathbf{c m}^{-2}\end{array}$ & $\begin{array}{l}\text { Area resistance, } \\
\qquad \Omega \mathrm{cm}^{2}\end{array}$ & $\begin{array}{c}\text { Open circuit } \\
\text { voltage, } U_{0}, V\end{array}$ & $\begin{array}{c}\text { Max. current } \\
\text { density, } j_{\text {max. }}, A \\
\text { cm }^{-2}\end{array}$ & $\begin{array}{l}\text { Area resistance, } \\
\qquad \Omega \mathrm{cm}^{2}\end{array}$ & $\begin{array}{l}\text { Open circuit } \\
\text { voltage, } U_{0}, V\end{array}$ & $\begin{array}{c}\text { Max. current } \\
\text { density, } j_{\text {max. }}, \\
\quad \mathbf{A ~ c m}^{-2}\end{array}$ & $\begin{array}{c}\text { Area resistance, } \\
\qquad \mathrm{cm}^{2}\end{array}$ \\
\hline Pths & 1.012 & 1.35 & -0.279 & 0.987 & 1.05 & -0.353 & 0.000 & 1.25 & 0.165 \\
\hline Ptpv3 & 0.984 & 1.35 & -0.292 & 0.981 & 1.05 & -0.353 & 0.000 & 1.25 & 0.161 \\
\hline Pt-Copv3 & 1.004 & 1.00 & -0.424 & 0.963 & 0.70 & -0.555 & 0.001 & 1.00 & 0.217 \\
\hline
\end{tabular}

the polarization curve procedure. In an EHP, $j_{\max }$, is established when the cell voltage exhibits a steep increment of $>0.1 \mathrm{~V}$ within a single constant

current density step during the polarization curve procedure, indicating water transport limitations within the PEM. 


\section{Figure Captions}

Fig. 1. Diagrams of the proton-exchange membrane devices. a) A PEMFC connected to a direct current (D.C.) electronic load. b) A typical electrochemical hydrogen pump connected to a D.C. power supply. The devices are galvanic and electrolytic cells, respectively.

Fig. 2. MEA manufacture process and equipment. a) Steps in the preparation of the MEAs, b) ultrasonic bath, c) 6-tonne hot-press, d) PTFE aligning stencil, e) aluminium plate with aligning pins, f) suction-feed airbrush, g) laser cutter, h) $5 \mathrm{~cm}^{2}$ cell with graphite monopolar plates, and i) fuel cell test station.

Fig. 3. Effect of airbrush type on the surface morphology of the Pths catalyst layer on carbon paper pre-coated with microporous carbon (for laboratory use). Spray distance approx. $15 \mathrm{~cm}$. a) Catalyst layer produced by a gravity-feed airbrush, catalyst loading 0.3

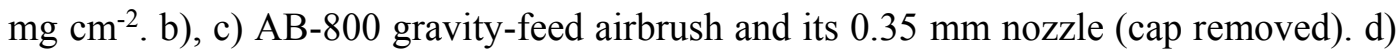
Catalyst layer produced by a suction-feed airbrush, catalyst loading $0.3 \mathrm{mg} \mathrm{cm}^{-2}$. e), f) HS-182 suction-feed airbrush and its $0.5 \mathrm{~mm}$ nozzle (cap removed). For SEM images magnification is $100 \times$.

Fig. 4. Effect of airbrush type on the polarisation curve of MEAs prepared with PtHS benchmark catalyst. a) PEMFC, $\mathrm{H}_{2}$ flow rate $70 \mathrm{~cm}^{3} \mathrm{~min}^{-1}$ and $\mathrm{O}_{2}$ flow rate $70 \mathrm{~cm}^{3} \mathrm{~min}$. $^{-}$

${ }^{1}$. b) Electrochemical hydrogen pump, $\mathrm{H}_{2}$ flow rate and pressure were $70 \mathrm{~cm}^{3} \mathrm{~min}^{-1}$ and $100 \mathrm{kPa}$ in both half-cells. Cell temperature $80^{\circ} \mathrm{C}$, gas lines and humidifiers temperature $78^{\circ} \mathrm{C}$. Gas pressure in each half-cell $100 \mathrm{kPa}$. 
Fig. 5. Surface morphology of the evaluated catalysts as a function of their loading as sprayed on carbon paper pre-coated with microporous carbon. For the anode, a loading of $0.1 \mathrm{mg} \mathrm{cm}^{-2}$ : a) Pths, b) PtPv3, and Pt-Copv3 catalysts. And for the cathode, a loading of $0.3 \mathrm{mg} \mathrm{cm}^{-2}$ : a) Pths, b) PtPv3, and Pt-Copv3 catalysts. SEM images, magnification $250 \times$.

Fig. 6. Polarisation curves of MEAs prepared with different catalysts using pure $\mathrm{O}_{2}$ in PEMFC mode. Cell temperature $80^{\circ} \mathrm{C}$, gas lines and humidifiers temperature $78^{\circ} \mathrm{C} . \mathrm{H}_{2}$ flow rate $70 \mathrm{~cm}^{3} \min ^{-1}$ and $\mathrm{O}_{2}$ flow rate $70 \mathrm{~cm}^{3} \mathrm{~min}^{-1}$. Gas pressure in each half-cell 100 $\mathrm{kPa}$. Anode and cathode loading of $0.1 \mathrm{mg} \mathrm{cm}^{-2}$ and $0.3 \mathrm{mg} \mathrm{cm}^{-2}$, respectively.

Fig. 7. Polarisation curves of MEAs prepared with different catalysts using air in PEMFC mode. Cell temperature $80^{\circ} \mathrm{C}$, gas lines and humidifiers temperature $78^{\circ} \mathrm{C} . \mathrm{H}_{2}$ flow rate $70 \mathrm{~cm}^{3} \mathrm{~min}^{-1}$ and air flow rate $300 \mathrm{~cm}^{3} \mathrm{~min}^{-1}$. Gas pressure in each half-cell $100 \mathrm{kPa}$. Anode and cathode loading of $0.1 \mathrm{mg} \mathrm{cm}^{-2}$ and $0.3 \mathrm{mg} \mathrm{cm}^{-2}$, respectively.

Fig. 8. Polarisation curves of MEAs the evaluated in electrochemical hydrogen pump operation. Cell temperature $80{ }^{\circ} \mathrm{C}$, gas lines and humidifiers temperature $78{ }^{\circ} \mathrm{C} . \mathrm{H}_{2}$ flow rate and pressure were $70 \mathrm{~cm}^{3} \mathrm{~min}^{-1}$ and $100 \mathrm{kPa}$ in both half-cells. Anode and cathode loading of $0.1 \mathrm{mg} \mathrm{cm}^{-2}$ and $0.3 \mathrm{mg} \mathrm{cm}^{-2}$, respectively. 


\section{PEM fuel cell}

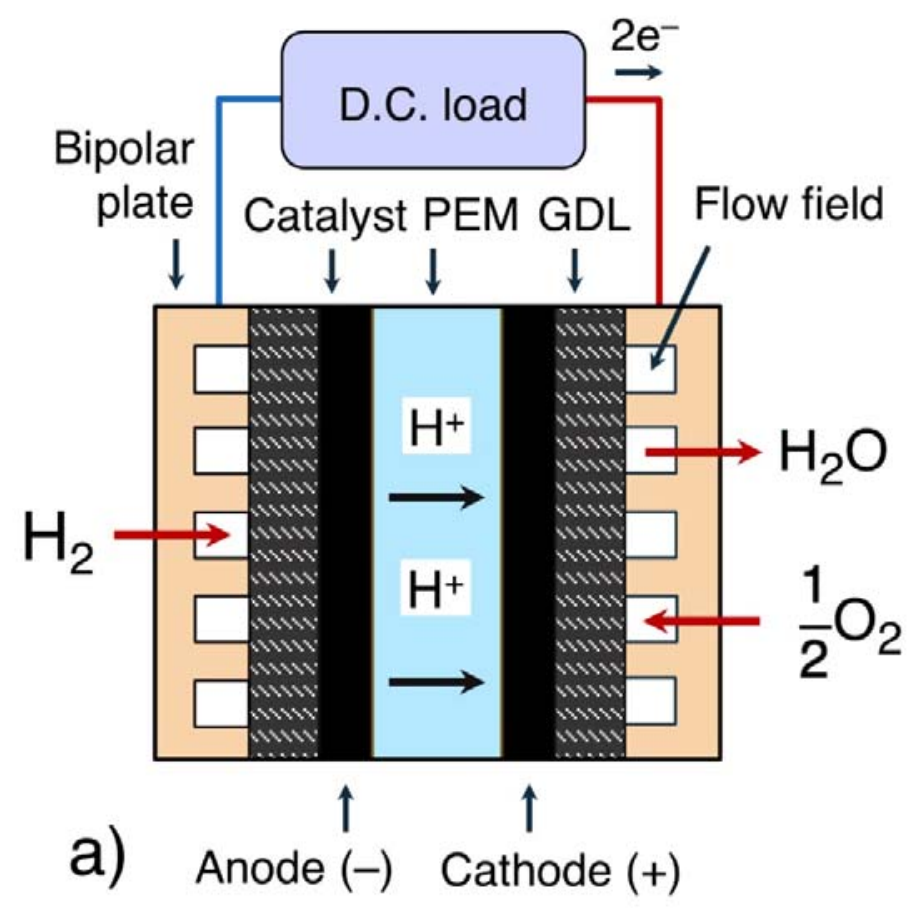

\section{Hydrogen pump}

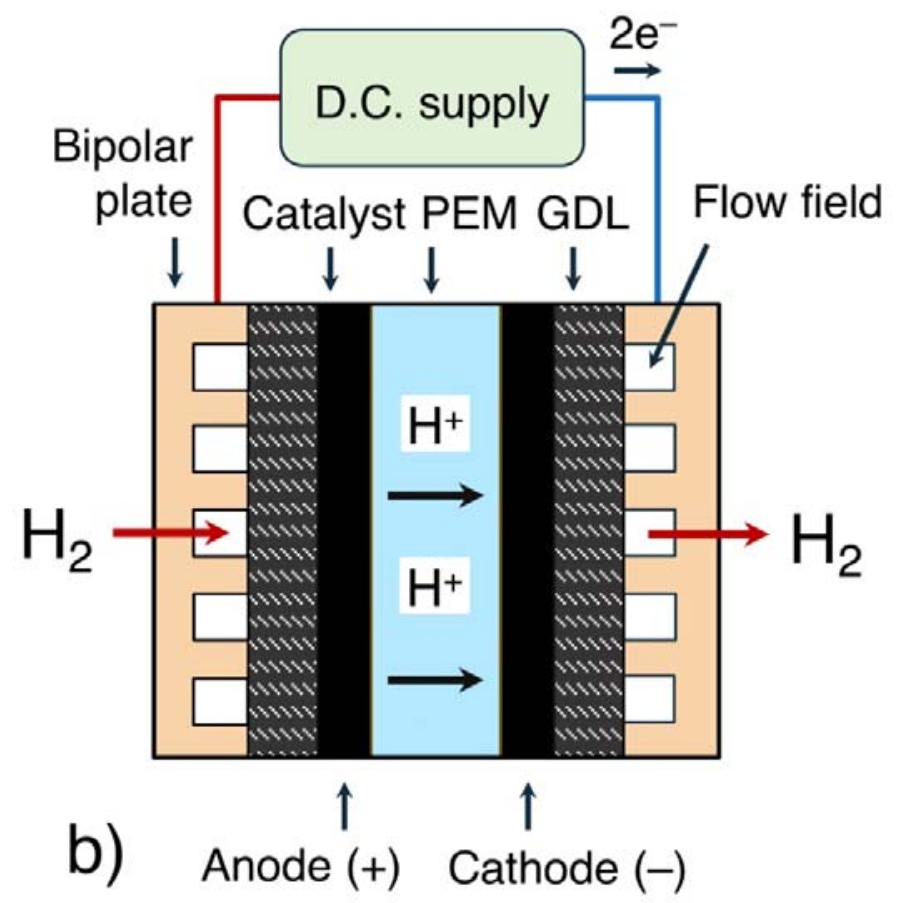

Figure 1 

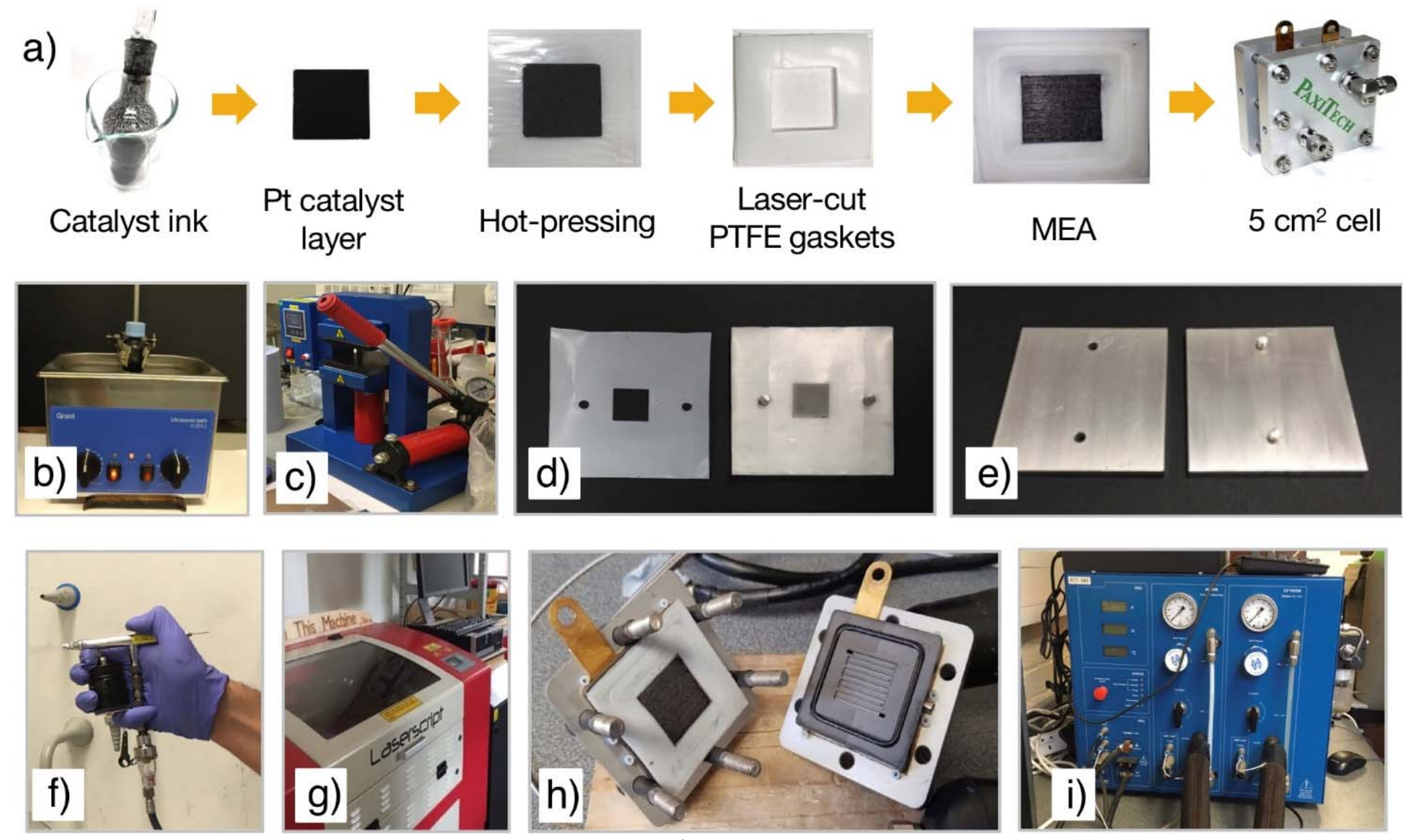

Figure 2 

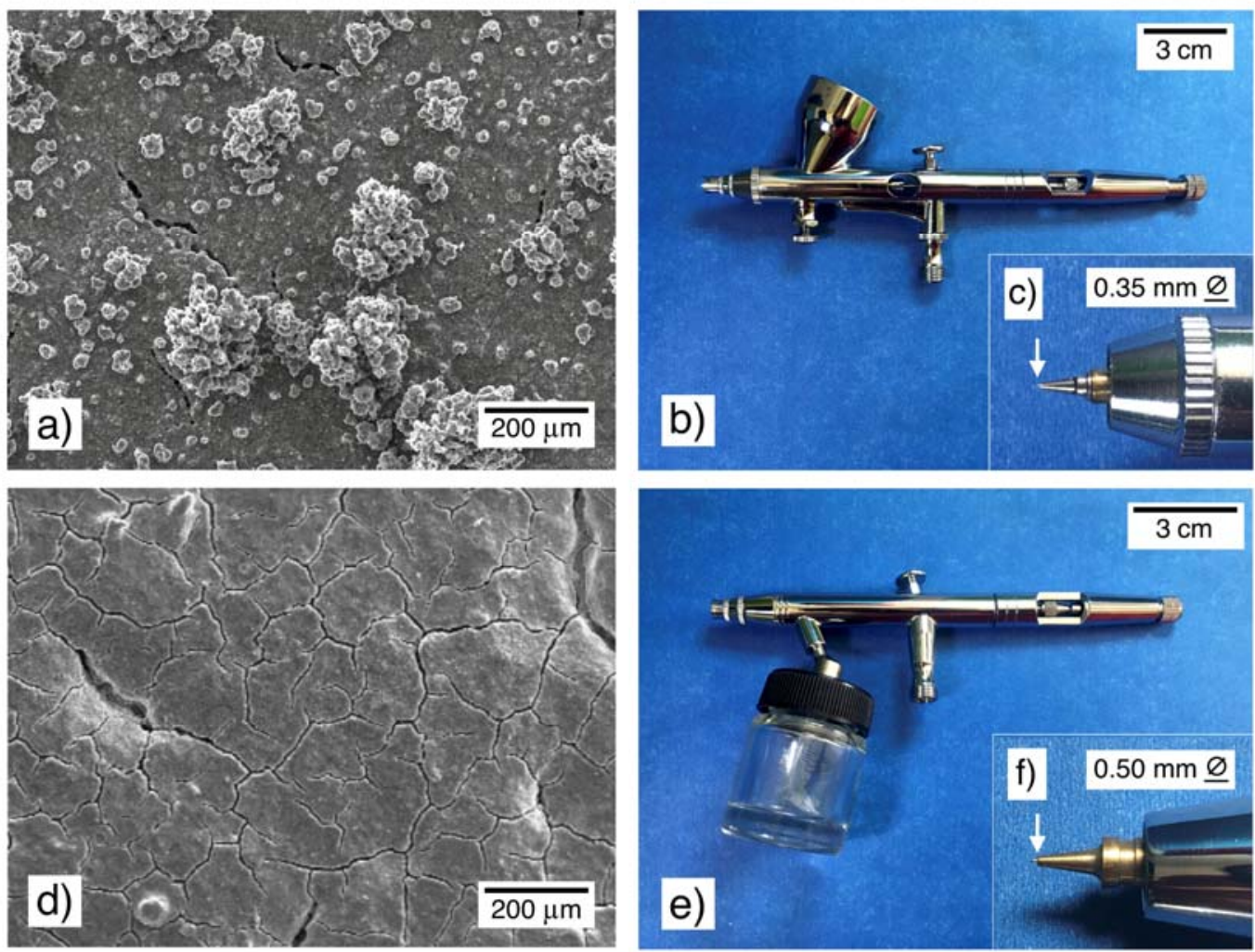

Figure 3 

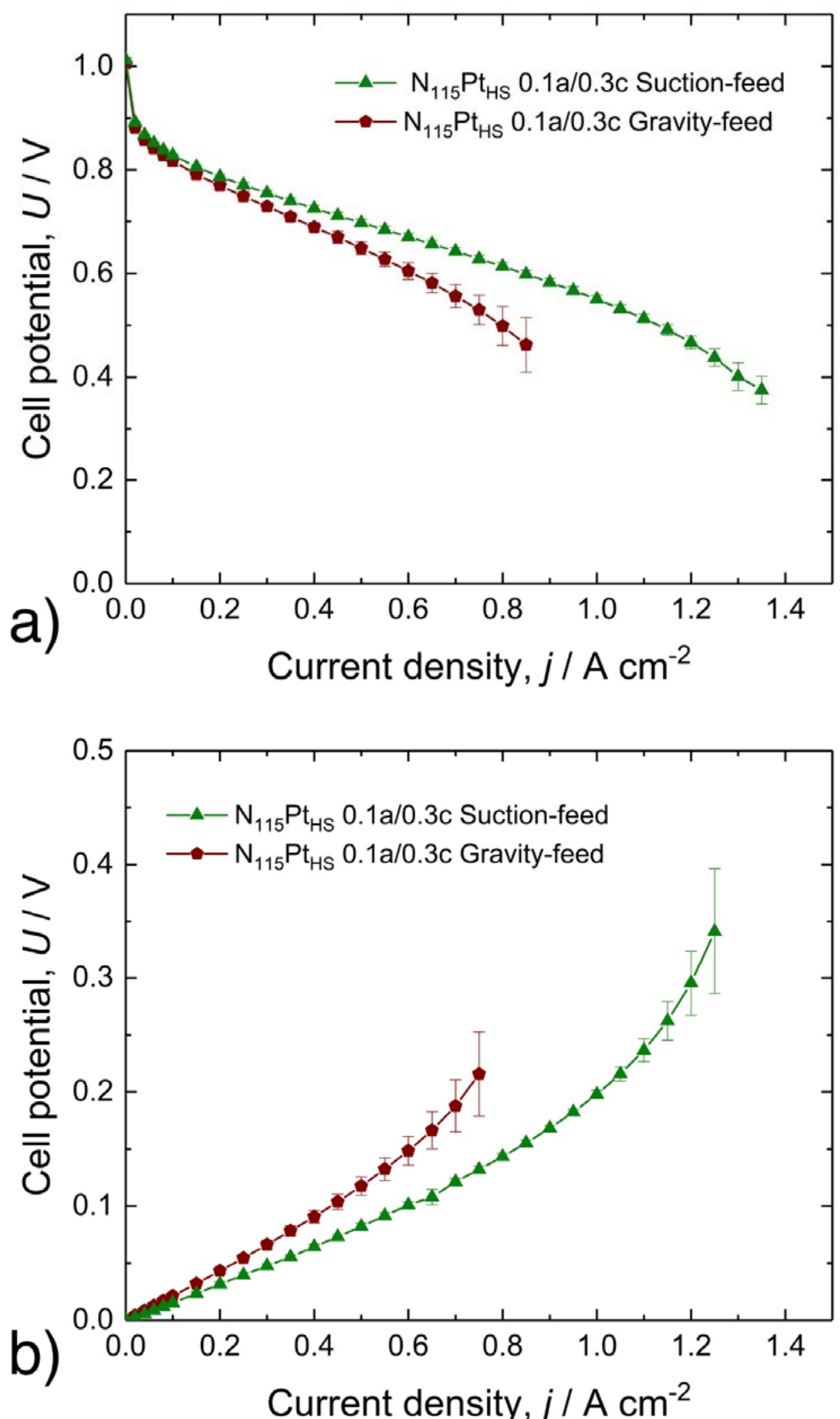

Figure 4 

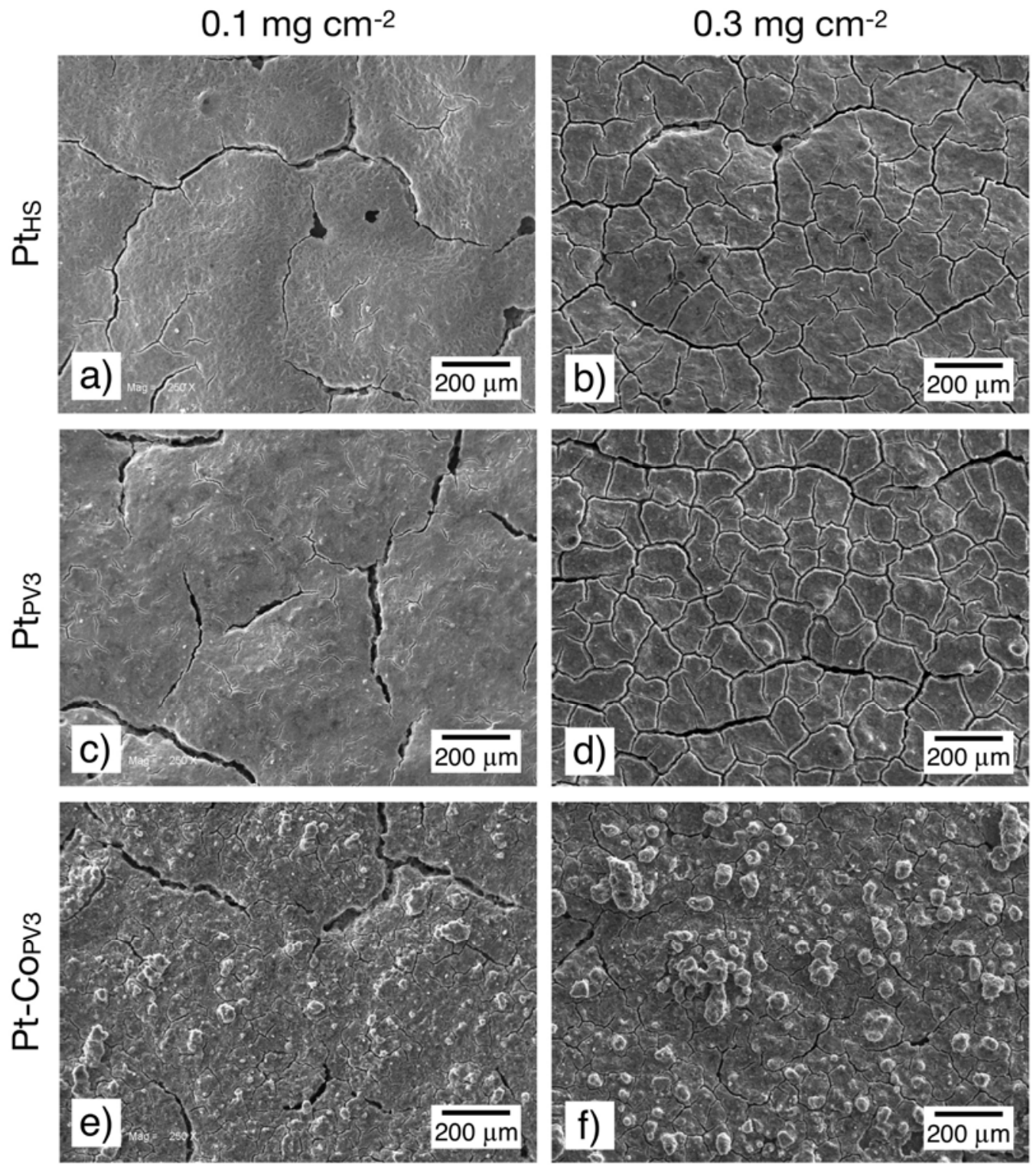

Figure 5 


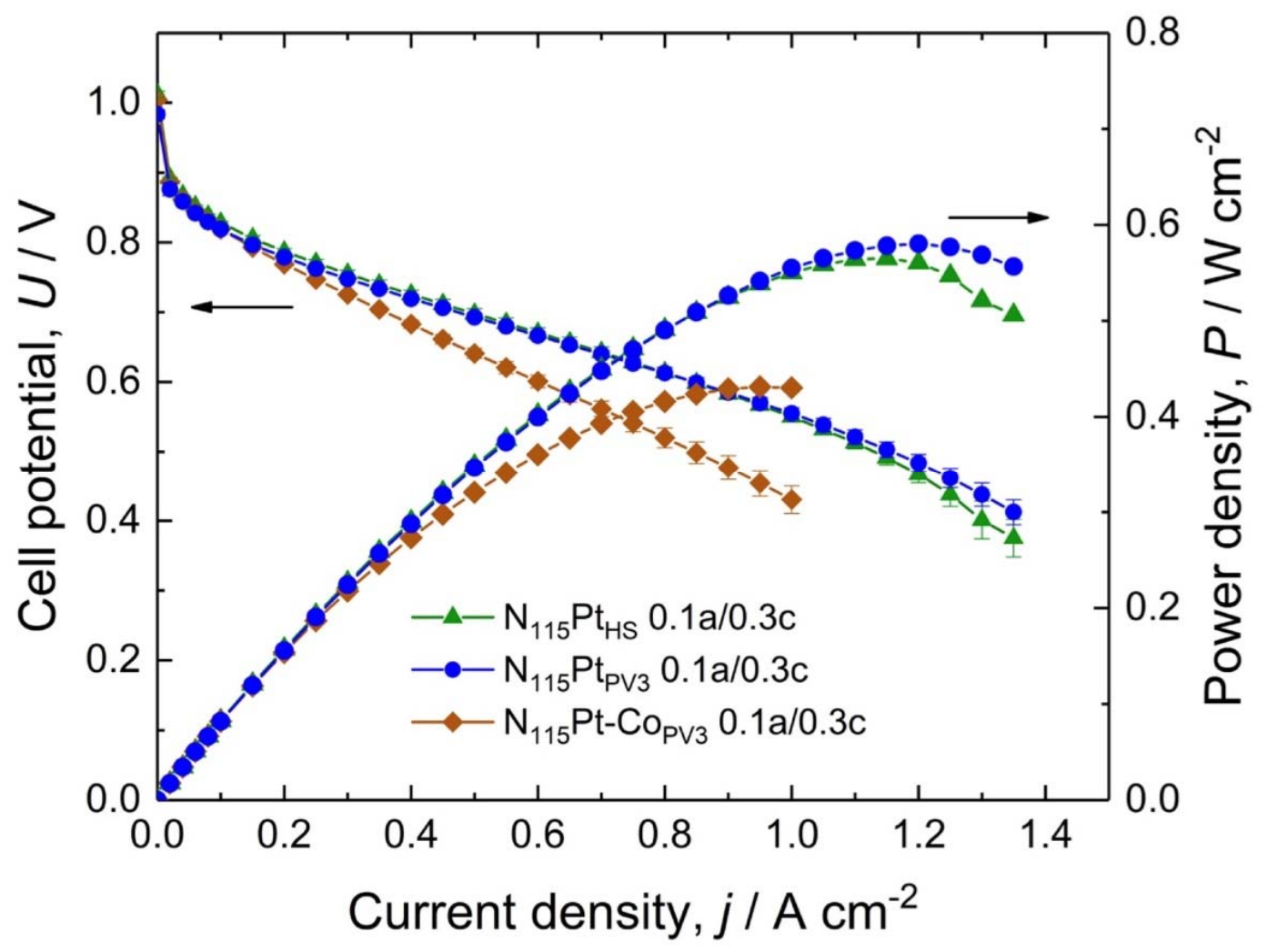

Figure 6 


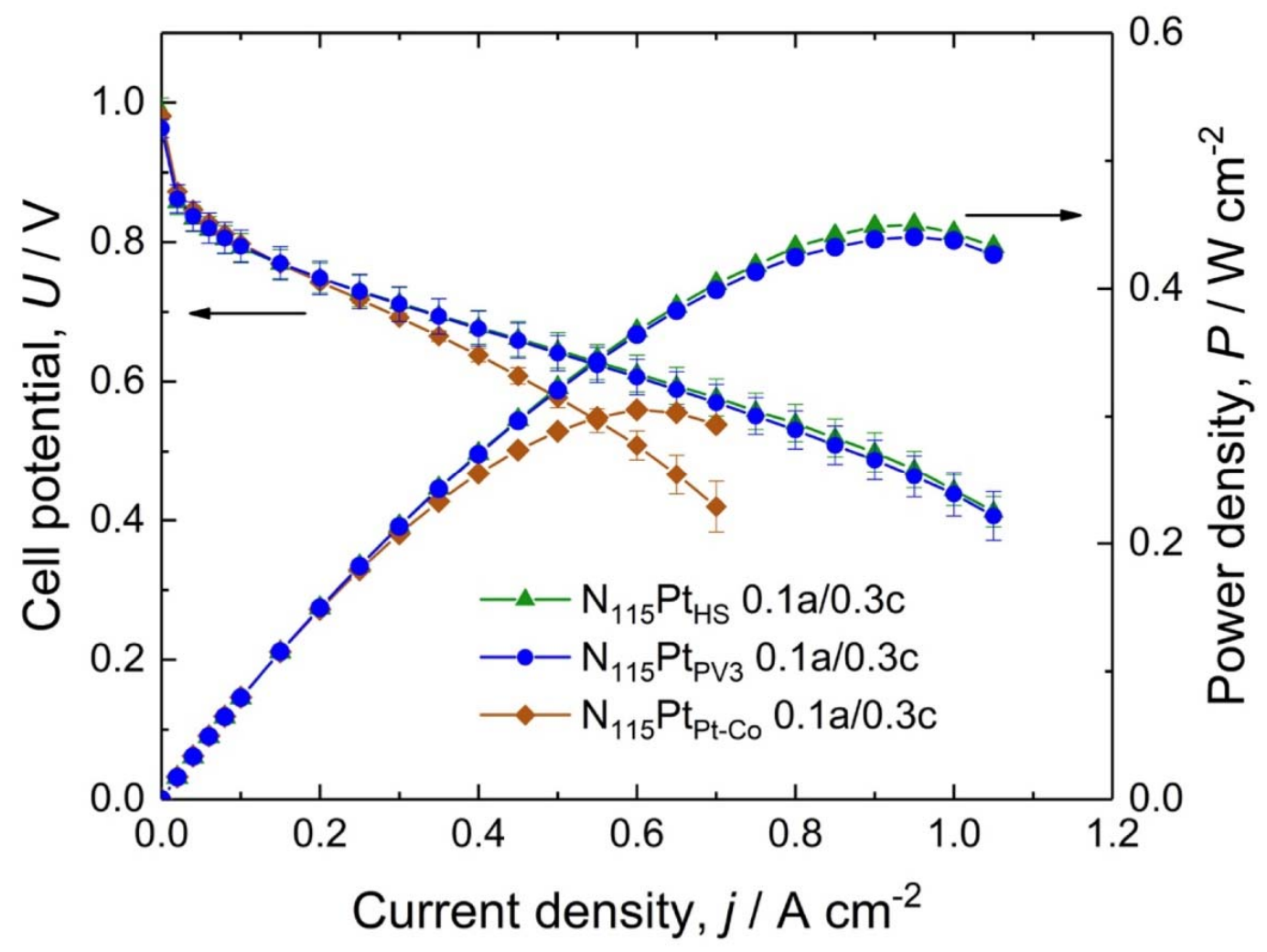

Figure 7 


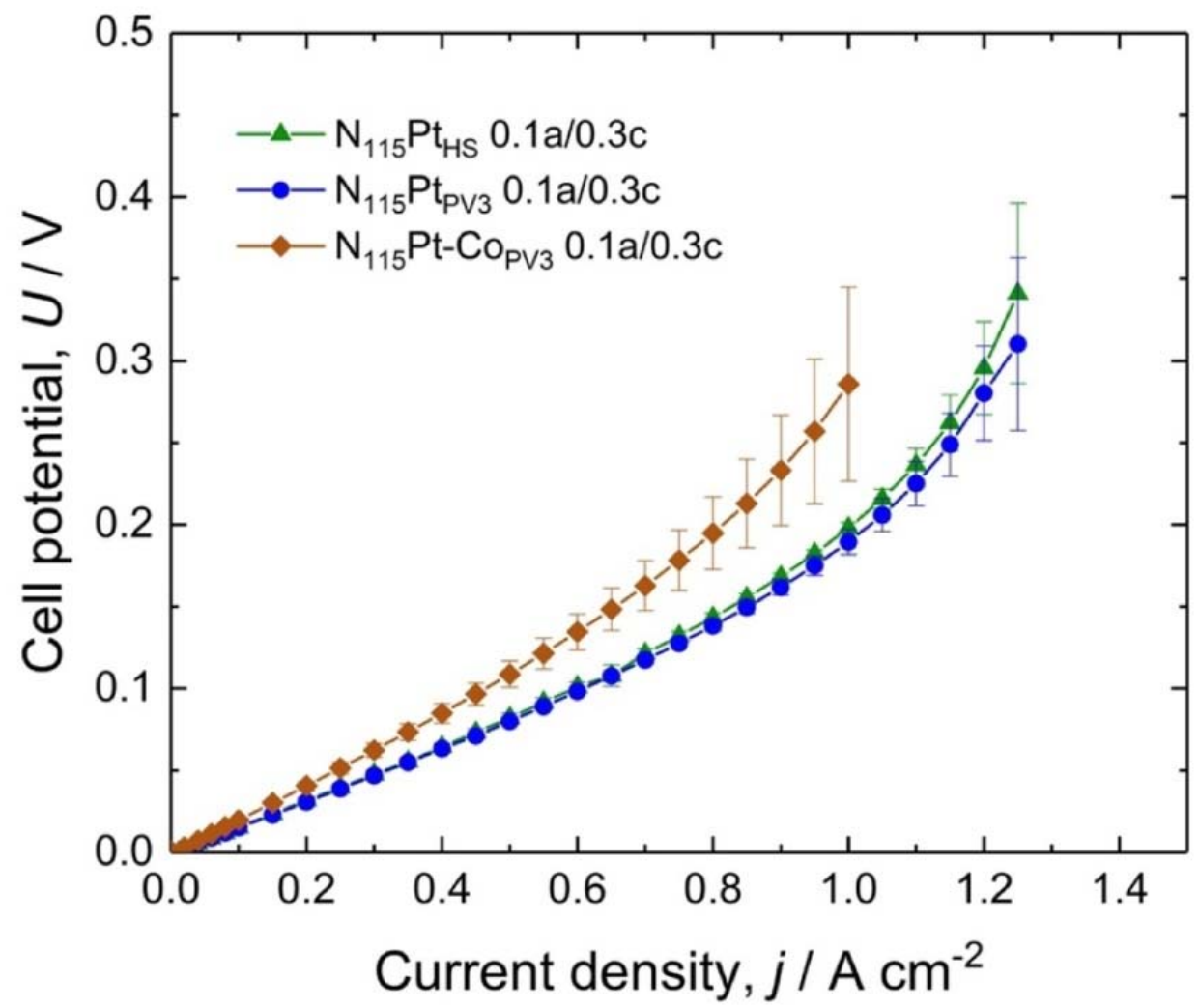

Figure 8 